\title{
Installation of a Riparian Forest by Means of Soil Bio Engineering Techniques-Monitoring Results from a River Restoration Work in Southern Brazil
}

\author{
Hans Peter Rauch ${ }^{1}$, Fabricio Sutili ${ }^{2}$, Stephan Hörbinger ${ }^{1}$ \\ ${ }^{1}$ Department for Civil Engineering and Natural Hazards, University of Natural Resources and Life Sciences, \\ Institute of Soil Bioengineering and Landscape Construction, Vienna, Austria \\ ${ }^{2}$ Departamento de Ciências Florestais, Universidade Federal de Santa Maria, Santa Maria, Brazil, \\ Email: hp.rauch@boku.ac.at, fjsutili@gmail.com
}

Received December $1^{\text {st }}$, 2013; revised January $6^{\text {th }}, 2014$; accepted January $26^{\text {th }}, 2014$

\begin{abstract}
Copyright (C) 2014 Hans Peter Rauch et al. This is an open access article distributed under the Creative Commons Attribution License, which permits unrestricted use, distribution, and reproduction in any medium, provided the original work is properly cited. In accordance of the Creative Commons Attribution License all Copyrights (C) 2014 are reserved for SCIRP and the owner of the intellectual property Hans Peter Rauch et al. All Copyright (c) 2014 are guarded by law and by SCIRP as a guardian.
\end{abstract}

Soil bioengineering has been applied more and more in different regions of Brazil in recent years. The study in hand presents the installation of "new" riparian forest based on soil bioengineering techniques. This riverbank restoration work was implemented in the year 2010 and two onsite vegetation surveys, one shortly after the construction, and one in 2013. Besides that, the structures of reinforcement work, and its effectiveness were evaluated. By means of the vegetation survey, the applied species were examined for their ability to establish the riverbank in an environmentally sustainable way. Most notably, the species Calliandra brevipes Benth. (Fabaceae, Mimosoideae), Phyllanthus sellowianus Müller Arg. (Euphorbiaceae), Salix humboldtiana Willd. (Salicaceae), Bauhinia forficate Link (Leguminosae), Inga marginata Willd. (Mimosoideae) and Ateleia glazioveana Baill. (Leguminosae, Papilionoideae) showed a good growth development. The proportion of spontaneous vegetation increased significantly, with Pennisetum purpureum Schumach. becoming a dominating species. Resulting from that, the intervention can be assessed as functional and safe, but the strong increase of spontaneous vegetation is undesirable due to less flood resistance. The vegetated riprap could be the best to meet the expectations of the construction elements. Partly, the anchored willows showed as well a good growth development whereas the species used for the hedge brush layer could not develop as expected in large parts of the construction.

Keywords: Soil Bioengineering; Riverbank Restoration; Riparian Forest; Rio Grande do Sul

\section{Introduction}

In the recent past, soil bioengineering projects carried out in Brazil were done in the region of Rio Grande do Sul within river stabilization works, to protect agricultural land of small regional farmers. The soil bioengineering techniques, which are the use of living plant material for civil engineering structures, can be a helpful instrument for civil engineers taking into account not only technical but also ecological, sustainable and socio-economical aspects. These methods have meanwhile regained worldwide recognition for their use in river and civil engineering projects (Howell, 1999; Acharya et al., 2005; Durlo et al., 2005; Li et al., 2002; Lammeranner et al., 2005; Wu et al., 2006; Petrone et al., 2008; Petrone et al., 2010). The principle of biological engineering constructions is based on the combination of dead and living materials and the emerging positive synergistic effects. The dead auxiliaries (stone, wood, etc.) protect the living plants until they undertake technical functions. After several years, a part of the auxiliary material rots and the stabilization of the bank is secured by the plants (Gerstgasser, 2000; Schiechtl, 1980; Howell, 1999; Florineth,
2002; Durlo et al., 2005; Zeh, 2007; AMEC Environment \& Infrastructure, 2012; Sutili et al., 2012; Acharya et al., 2008).The riparian vegetation has a major role in the river-bank's protection, through the roots system and the plant cover, improving the soil particles aggregation in a low cohesion situation, reducing the runoff and resulting in a lower erosion rate and sedimentation of the river channel (Holanda \& Pinheiro da Rocha, 2010). Previous research already assessed some potentially useful plants for soil bioengineering works. Several studies have already been performed to investigate native, riparian species, their biological and technical properties, and soil bioengineering structures for their applicability in restoration works in Rio Grande do Sul (Altreiter \& Plunger, 2004; Sutili et al., 2004; Durlo \& Sutili, 2005; Florineth et al., 2006; Denardi, 2007; Vargas, 2007; Monteiro, 2009; Rauch, \& Sutili, 2009). The acquired knowledge can be applied to the spreading area of the plants and in this way, it can be useful in various regions. This case study presents an intervention applied at the end of 2010, at the River Pardinho in the state of Rio Grande do Sul. The riverbank restoration became essential due to a combina- 
tion of hydraulic induced erosion and bank mass failure. Bank mass failure resulted from fluvial erosion at the toe of the bank with a continuous removal of bank material, affecting a change in the bank slope by over deepening the bank and altering its angle. Additionally to the forces of the running water, surcharge from the weight of trees on the top of the slope accelerated the erosion process. Surcharge and near-surface moisture are, according to Simon and Collison (2002), destabilization effects that can affect slope stability. The objective of this study was 1) to document the implementation of soil bioengineering techniques and 2) to perform a comprehensive vegetation survey in combination with an assessment of the slope stability, examining the midterm effect and functionality of dense vegetation on slope reinforcement and the durability of soil bioengineering constructions. It is of high interest to analyze the vegetation after a certain period and evaluate the used species in order to be able to draft up efficient plant strategies for future riparian restoration works on degraded river embankments. Only in recent years, soil bioengineering has become more applied in Brazil. The research process in this field of study has been highlighting clear uncertainties in developing soil bioengineering standards from an engineering as well as from an environmental point of view.

\section{Materials and Methods}

\section{Location}

The River Pardinho, a tributary to the River Jacuí, is located in the watershed of the River Pardo, in the central region of the state of Rio Grande do Sul. The section where the intervention was realized is situated downstream of a reservoir dam which provides the water supply for the municipality of Santa Cruz do Sul with 119.057 inhabitants (Heuser, 2013).The Pardo River basin is comprised of areas with a difference in altitude of up to $500 \mathrm{~m}$. Approximately $40 \%$ of its total area applied to the middle portion of the basin, where the municipal seat of Sinimbu is located, with altitudes ranging from $200 \mathrm{~m}$ to $500 \mathrm{~m}$. The downstream (lower part) of the basin, where Santa Cruz do Sul is located, is characterized through flat areas with a slightly undulating relief (Commitê Pardo, 2011). According to Moreno (1961), the local climate is subtropical, with humid climatic conditions, hot summers and rainfall during all seasons. However, in months of high temperatures, hydrological deficits can occur. During the rainy season, the area is sometimes prone to extreme flash flood conditions. The slope reinforcement construction was implemented at an actively eroding bank section at the left side of the river with more than $80 \mathrm{~m}$ in length (see Figure 1).

\section{The Causing of the Eroding Process}

The instability of the bank resulted from a continuous process of erosion, landslide, collapse and remove a lot material due to the action of the watercourse (see Figure 2).

The latter has shifted its axes outwards on this slightly curving river section. The instability of the embankment was exacerbated by the steep angle of the embankment, preventing the vegetation from spontaneous establishment. Additionally, the vegetation that was planted initially along the river at the top of the margin (trees of Enterolobium contortisiliquum (Vell.) Morong) did not have any stabilization effect on the site. Actually quite the reverse occurred. This vegetation formed an overhead
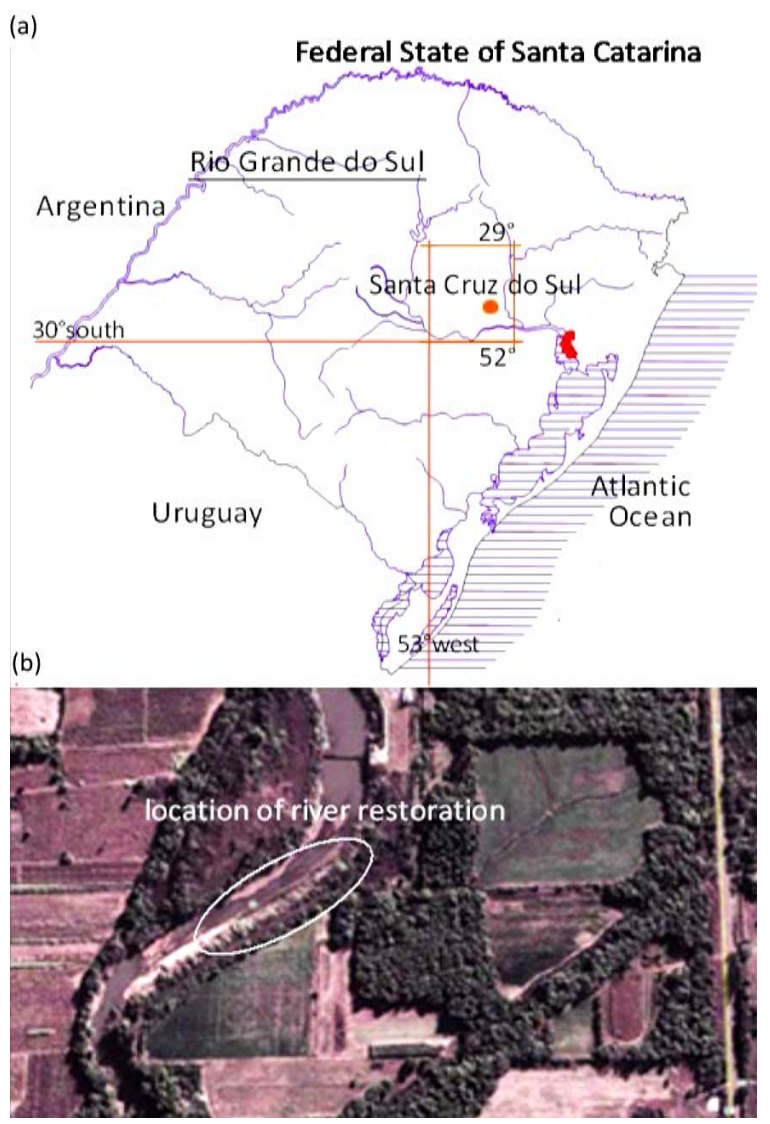

Figure 1.

(a) The location of Santa Cruz do Sul in the state of Rio Grande do Sul and the states big watercourses; (b) The location where the river restoration work was implemented.

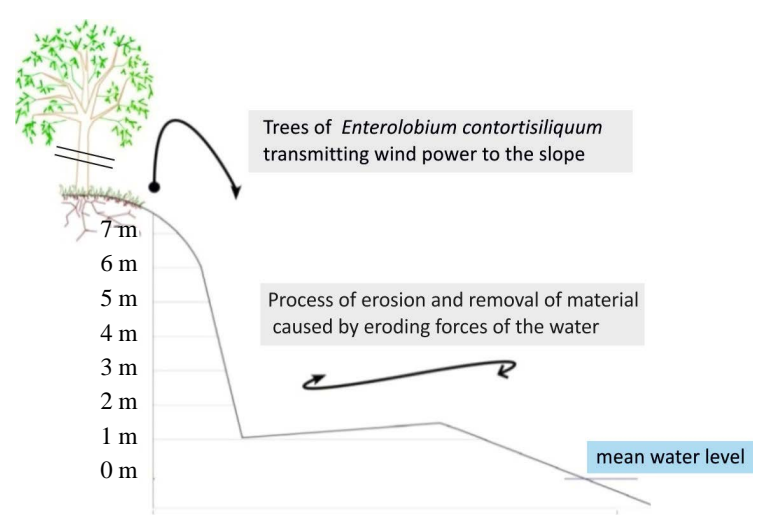

Figure 2.

Sectional view, illustrating the eroding process.

in the vertical axes, shifting its center of gravity in a less stable position. It captures and transmits wind power to the slope, creating a lever that certainly amplifies the dynamics of landslides, triggered by the current of the stream (Durlo \& Sutili, 2005).

\section{Methodology of Vegetation Survey and Evaluation of Construction}

In the end of November 2010, two months after the last inter- 
ventions had been completed; a vegetation survey was carried out in order to analyze the growth pattern of the plant stand. Therefore, 10 stripe-shaped transects where staked out along the riverbank. Each parcel had an area of $2 \mathrm{~m}$ in width and 15 $\mathrm{m}$ in length, extending from the water level to the highest point of the slope. By dividing the transects into sub-sampled portions of $1 \mathrm{~m} \times 2 \mathrm{~m}$, it was possible to recognize the variation along each parcel. In this way, it facilitated the interpretation of the data according to their variation along the gradient of the slope and individualize their analysis in accordance to the construction. Additionally to the classification of the plant individuals, the stem diameter at base and the plant height were measured.

At the end of January 2013, a second vegetation survey was carried out in order to examine the long term effects of the riverbank restoration and the development of species with their actual distribution. For this survey, the same methodology as for the first one was used in order to be able to compare the results of each parcel and sub parcel with the previous data. Supplementary, in the second survey the crown diameter and the number of shoots were measured, the coverage rate by using the method of "Braun Blanquet" was estimated and a classification of the plant's vitality, in four classes, was performed. An integral assessment method was developed to evaluate the status and the effectiveness of the constructions four classification classes were each defined (see Table 1).

\section{Results}

\section{Intervention-Application of Soil Bioengineering Methods}

The presented intervention was composed of two complementary and inseparable parts: the physical actions and the implementation of vegetation. The physical constructions and first vegetative interventions were done from January to Febru- ary in 2010. The intervention was executed in the following sequence: Firstly, the vegetated riprap was realized by using Calliandra brevipes Benth. and hardwood cuttings of Salix humboldtiana Willd. Above, hedge brush layers of the species Terminalia australis Cambess. Schinus molle L., Schinus terebentifolia Raddi. and Pouteria salicifolia (Spreng.) Radlk. were installed. In the upper portion, trees of Salix humboldtiana were anchored to the slope, using wooden poles and steel wires. Even further up, in the same way, trees of Enterolobium contortisiliquum were anchored to the slope but without the expectation of sprouting. As a final measure, the top angle of the slope was corrected and seedlings and hardwood cuttings of Phyllanthus sellowianus Müll. Arg. were fielded on its middle portion. After heavy rainfalls, a second vegetative intervention was implemented to ensure the physical integrity of the margin. Its purpose was to support the vegetated riprap, the hedge brush layer and the anchored willows. Particularly as the anchored trees of Enterolobium contortisiliquum had been removed during the heavy-rainfalls, an additional action became necessary. The aim is to enhance the biodiversity on site, but also for testing various species in terms of their applicability for soil bioengineering interventions a wide range of species was used. Figure 3 shows a technical sketch with all the applied soil bioengineering techniques and the used plants. The plant material consisted of 1550 seedlings of 32 native species.

\section{Species Observed in Each Section of the Construction}

The vegetation surveys were conducted in 2010 and 2013 as described in the methodology chapter. Figure 4 shows an overview of all sections.

\section{Section 1-Vegetated Riprap}

In the segment of the vegetated riprap, three kinds of species were observed in the first survey, namely: Calliandra brevipes

Table 1.

Integral assessment method to evaluate the status and effectivity of structures and the vitality of species.

\begin{tabular}{|c|c|c|c|}
\hline Classification & Status Class & Effectiveness Class & Vitality Class \\
\hline 1 & $\begin{array}{l}\text { Good: Both the supporting, technical structure (inert } \\
\text { materials) as well as the used plant material is in a visible } \\
\text { good state. There is no visible external damage indicating } \\
\text { an imminent failure of the structure and the used plants are } \\
\text { well established. }\end{array}$ & $\begin{array}{l}\text { Good: The resulting effect to } \\
\text { the respective intervention is } \\
\text { highly achieved and is clearly } \\
\text { visible. }\end{array}$ & $\begin{array}{l}\text { Exceedingly strong developed: } \\
\text { leaves lush green in color, high leaf } \\
\text { mass, strong shoots development } \\
\text { and growth in length }\end{array}$ \\
\hline 2 & $\begin{array}{l}\text { Slight damage of construction or little dominance of } \\
\text { invasive vegetation: Slight damage of the technical } \\
\text { structure or plants is observable. The living material will be } \\
\text { able to compensate for the harmful effect by its growth and } \\
\text { mechanical skills and it will not result in failure of the } \\
\text { structure. The used plant material is well established and } \\
\text { less or no invasive vegetation is present. }\end{array}$ & $\begin{array}{l}\text { Sufficient: The ascribed effect } \\
\text { to the respective intervention is } \\
\text { largely achieved and is clearly } \\
\text { visible, but not quite as } \\
\text { remarkable as in the rating } \\
\text { "good". }\end{array}$ & $\begin{array}{l}\text { Well developed: leaves lush green } \\
\text { in colour, little less leaf mass, } \\
\text { weaker shoots development and } \\
\text { growth in length }\end{array}$ \\
\hline 3 & $\begin{array}{l}\text { Severe damage of construction or strong dominance of } \\
\text { invasive vegetation: Both, the technical structure (inert } \\
\text { materials) as well as the used plants show external damage } \\
\text { or are largely suppressed by invasive plants which became } \\
\text { predominant. In the case that the invasive species can not } \\
\text { compensate the stability of the used vegetation it can be } \\
\text { assumed that an utter failure is imminent }\end{array}$ & $\begin{array}{l}\text { Still sufficient but obvious } \\
\text { deficiencies: The ascribed } \\
\text { effect to the respective } \\
\text { intervention is barely achieved } \\
\text { but still visible. }\end{array}$ & $\begin{array}{l}\text { Poorly developed: leaves } \\
\text { yellow-green in colour, little leaf } \\
\text { mass, very weak shoots } \\
\text { development and growth in length. }\end{array}$ \\
\hline 4 & $\begin{array}{c}\text { Destructed: The structure is only rudimentarily observable } \\
\text { or not existing anymore and is to be classified as } \\
\text { ineffective. }\end{array}$ & $\begin{array}{l}\text { Insufficient: The ascribed } \\
\text { effect to the respective } \\
\text { intervention is not achieved. }\end{array}$ & Plant already dead or dying. \\
\hline
\end{tabular}




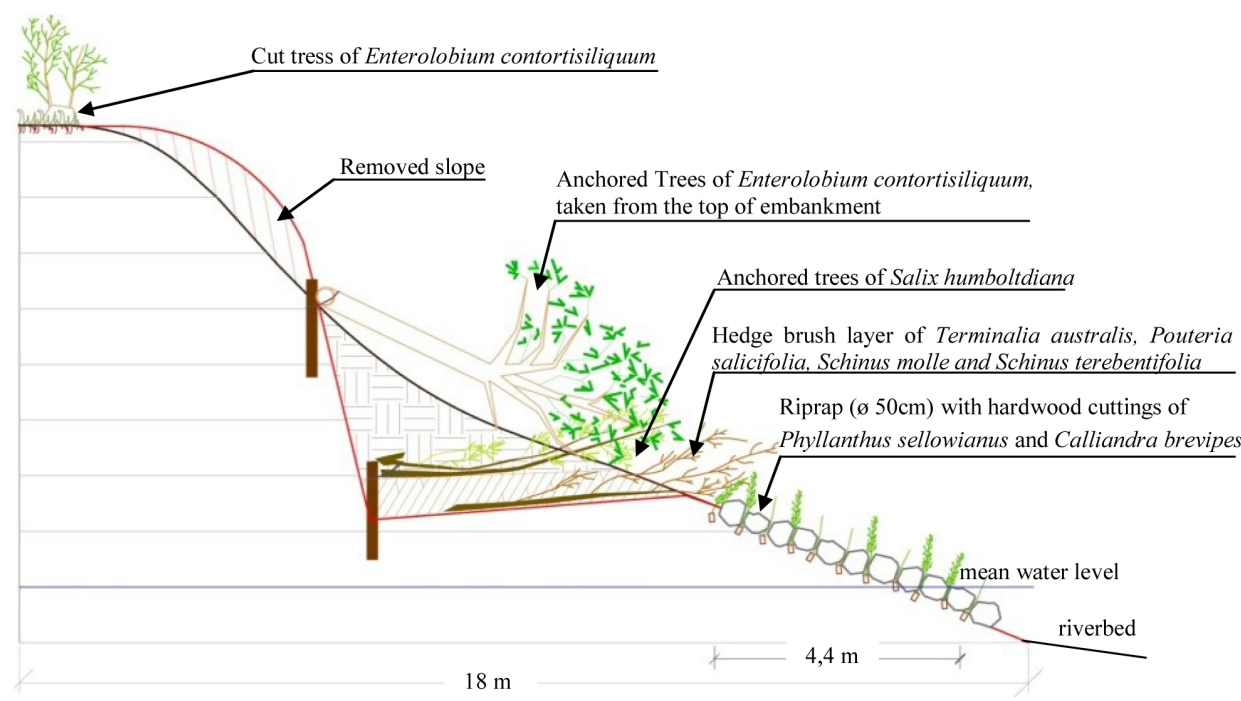

Figure 3.

Sectional view, illustrating the interventions taken at the embankment.

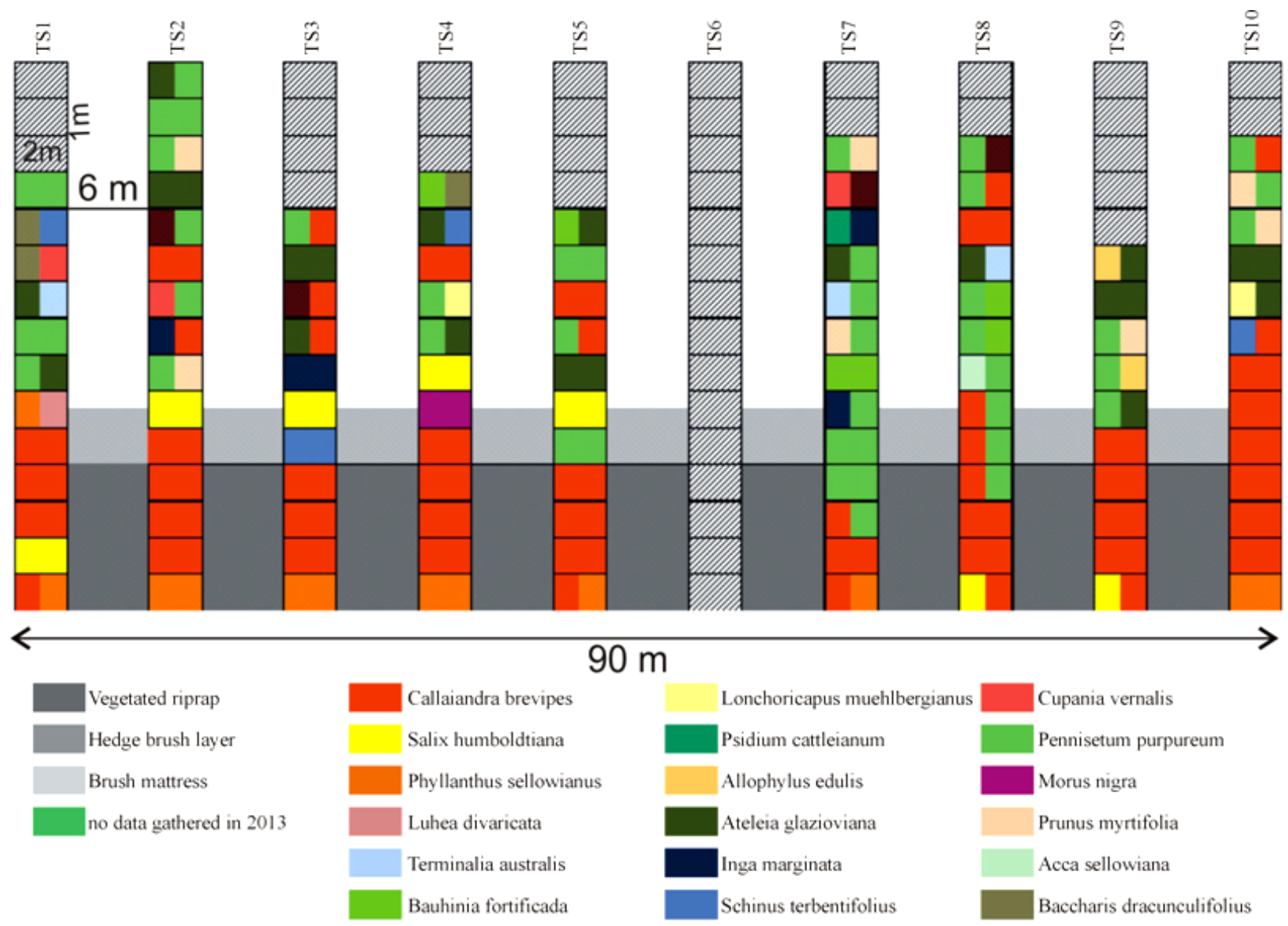

Figure 4.

Sectional view, illustrating the interventions taken at the embankment.

(51\% of specimens), Salix humboldtiana (43\% of specimens) and some plants which had emerged from the cuttings of Phyllanthus sellowianus ( $6 \%$ of specimens). These species have an average density of 2.6 plants per square meter. Compared to an initial density of 3.5 plants per square meter planted during the first intervention, $28 \%$ of seedlings had been lost in the first 8 months. These losses had occurred mainly in the segment closest to the mean water level, caused by long periods of submer- 
sion or by the flow. In the second plant survey the presence of the species was as follows; Calliandra brevipes (82\% of specimens), Phyllanthus sellowianus (10\% of specimens), Salix humboldtiana (5\% of specimens) and Terminalia australis (5\% of specimens). The density, now being 3.3 plants per square meter, shows that the plants could reproduce distinctly, in between the first- and second survey. In the lower part of the riprap, the dominating species were Calliandra brevipes (coverage rate [cr] of 39\%) and Phyllanthus sellowianus ([cr] 11\%) with some presence of Salix humboldtiana ([cr] 5\%). It can be assumed that these species can best support the hydraulic shear stress. With a coverage rate of 55\%, the uncovered area was extensive. Spontaneous vegetation was scarcely observed in this part. In the upper portion of the riprap, a strong dominance of Calliandra brevipes ([cr] 91\%) was noticeable. Just a few other individuals had been able to emerge in this section. Namely; Salix humboldtiana, Terminalia australis and some spontaneous vegetation, like Pennisetum purpureum Schumach., Sida sp. and Xanthium strumarium L. Only [cr] 2\% of the area was uncovered.

\section{Section 2-Hedge Brush Layer and Brush Mattress}

In the first vegetative survey, the following plants were observed in the sections of the hedge brush layer and anchored willows; the sprouting of Salix humboldtiana was prevalent, accounting for $59 \%$, and concentrated on the central portion. Terminalia australis, Morus nigra L. and Schinus terebentifolia were only found point wise. There was no sprouting of the hedge brush layer or the brush mattress in the transects 7, 8 and 9. In this portion, mainly the shrubs Schinus molle, Schinus terebentifolia and Pouteria salicifolia, which did not produce any shoots, had been used. The vegetation survey in 2013 showed the following situation in this section; Salix humboldtiana had diminished to a proportion of $31 \%$, still concentrating more in the central portion ([cr] 34\%). Terminalia australis completely disappeared. Morus nigra and Schinus terebentifolia still were observed only point wise. Calliandra brevipes ([cr] 10\%) had been able to spread in each part of the construction. Spontaneous vegetation had emerged over the whole length of the intervention and was partly dominant. Frequently, Poaceae sp. was found besides Pennisetum purpureum ([cr] 29\%) and constituted the second most prevalent group of spontaneous vegetation. The uncovered area was [cr] 9\%.

\section{Section 3-Plantations in the Upper Parts of the Slope}

The plants fielded in the second vegetative intervention in October 2010 showed mortality rate of only $2.6 \%$ two months after being fielded. In total, 273 plants were observed in the first survey. This number had decreased to 127 plant individuals in 2013. In the upper portion of the embankment, the greatest variety of species was found, although it had diminished distinctly from the first to the second survey. The diameter, as well as the plant height, had increased noticeably in this period of time. The vitality analysis showed that most of the species had developed very well. The amount of spontaneous vegetation was very high in this portion. As can be seen in Figure 4 and from the high coverage rate of $41 \%$, Pennisetum purpureum was dominant in several parts of the section. Other species with a considerable coverage rate are Ateleia glazioveana ([cr] 26\%), Calliandra brevipes ([cr] 9\%) and Bauhinia forficata ([cr] 4\%). The uncovered area was [cr] 7\%.

\section{Development of Species}

In Table 2, the species, which were found in the plant survey in 2011 but disappeared until 2013, are listed. Particularly strong losses were seen with the species Machaerium paraguariense Hassl., Eugenia myrcianthes Nied. and Myrcianthes pungens Berg. Legr. In Figure 5, the species, which were found in both vegetation surveys plus their mean plant height are shown. The species which developed best are Calliandra brevipes, Phyllanthus sellowianus, Ateleia glazioveana, Salix humboldtiana, Bauhinia forficata Link and Inga marginata Willd. In Figure 6, the growth development of these species is illustrated. Salix humboldtiana, showed great losses in the number of individuals. However, it grew very strong and highest of all species in the plant stand. The second highest grown species is Ateleia glazioveana. Its mean vitality was classified as 1 and only a few losses of plant individuals occurred. During the period of the monitoring, the plant individuals of Phyllanthus sellowianus increased and showed significantly the best growth along the mean water level. The plant individuals of Bauhinia forficata showed a good development. The same applies to Inga marginata, which could even increase the number of plant individuals. As well, Luehea divaricata Mart. and Inga marginata showed to be able to emerge on river embankments, as its number of individuals increased. Pouteria salicifolia, which was used in the hedge brush layer completely disappeared. Further species of the hedge brush layer are Morus nigra and Terminalia australis.

They were observed in the second survey but only in small number. Calliandra brevipes had the most significant increase of all applied species. The habitus is a small grown shrub, which produces many shoots. It can be assessed as a very dominating species, with the ability to grow on extreme conditions. Species which showed a good development but occurred only in a small number of individuals are Schinus terebentifolia, Schinus molle, Cupania vernalis Cambess. and Psidium cattleyanum Sabine.

\section{Evaluation of Structures}

In Figure 6, the evaluation of the structures in terms of effectiveness and status is shown. As a whole, the intervention can be assessed as functional and safe. The effectiveness of the structures in conjunction with the present vegetation is rated in the classification classes 1 or 2 . This means that the embankment is well protected and no imminent failure should be expected. Analyzing the structures separately showed some issues with the intervention. Only the vegetated riprap developed as it was supposed should have. In several spots, the implemented vegetation material did not or just sparsely emerge. Especially in the hedge brush layer and in the upper portion, where a wide range of species was fielded, the desired development was only partly achieved. The anchored willows showed a good development in half of the intervention, where high, vital brushes developed, making a major contribution to slope reinforce. In the other half, from transect 6 on, the brush mattresses could not develop at all. In the parts where the implemented vegetation did not develop as desired, spontaneous vegetation overtook the role of erosion protection, and therefore erosion just occurred point wise. Since the anchored trees of Enterolobium contortisiliquum were swept away shortly after planting, that intervention was classified with the category "destructed". Figure 7 shows the embankment before the restoration work in 2010 and after the monitoring in 2013. 
Table 2.

Species which disappeared between first and second survey.

\begin{tabular}{cccc}
\hline Name & Number specimens & Name & Number specimens \\
\hline Machaerium paraguariense Hassl. & 18 & Eugenia rostrifolia D. Legrand & 3 \\
Eugenia myrcianthes Nied. & 14 & Matayba eleagnoides Radlk. & 3 \\
Myrcianthes pungens Berg. Legr. & 8 & Tibouchina mutabilis (Vell.) Cogn. & 3 \\
Eugenia involucrata DC. & 5 & Aiouea saligna Meisn. & 2 \\
\hline
\end{tabular}

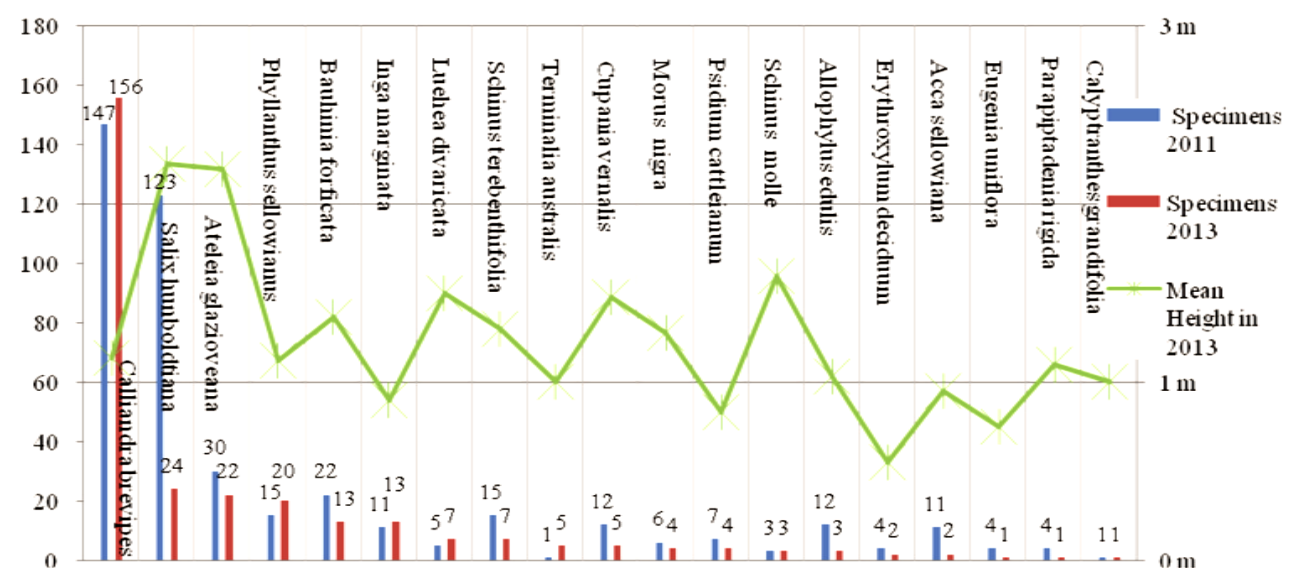

Figure 5.

Growth development of the species after 3 years of intervention.

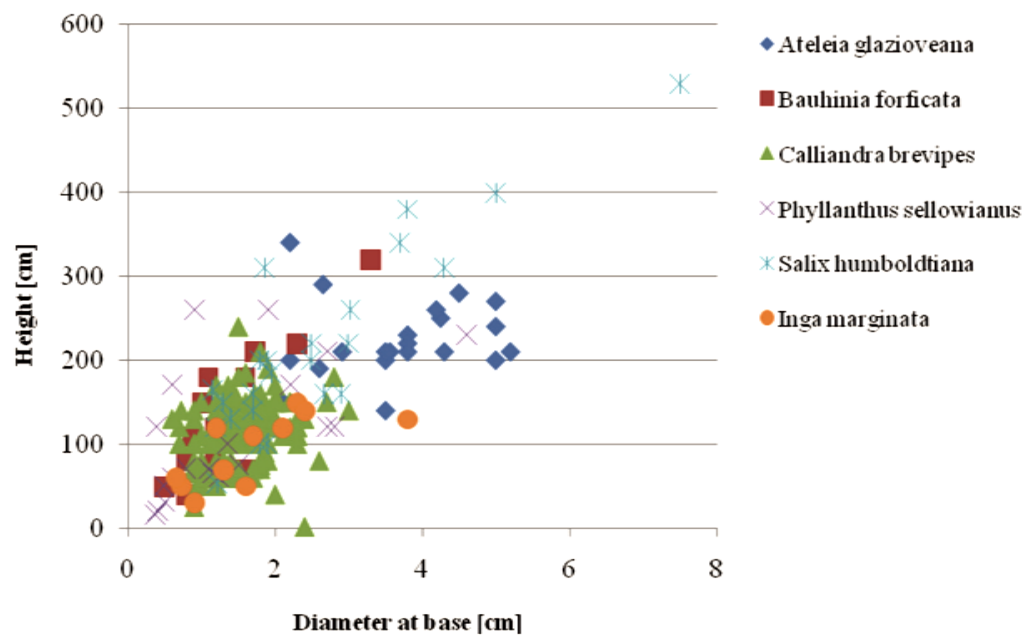

Figure 6.

Growth development of the species after 3 years of intervention.

Discussion on the Applicability of Most

Remarkable Species for Riverbank Restoration Works

The installation of "new" riparian forest depends on the technique of soil bioengineering method as well as on the used plants. Furthermore, the applied structures and some of the species, which are most decisive for the development of the embankment are discussed.

\section{Discussion of Applied Structures}

The installed vegetated riprap, was the most effective and stable construction applied. Realized by using relatively big basalt blocks, it is the less natural related construction of the applied structures. However, it provides considerably more habitats then in case of solid bank constructions. As the study shows, several species could emerge in the interstices of the basalt blocks. Through the changing of the temperature conditions and the position along the mean water level, it is a habitat for plants, tolerating extreme growth conditions. Moreover, its major contribution to the protection of the embankment enables an establishment of the plant stand above. In the hedge brush layer, it was observed that many species had diminished or disappeared. 


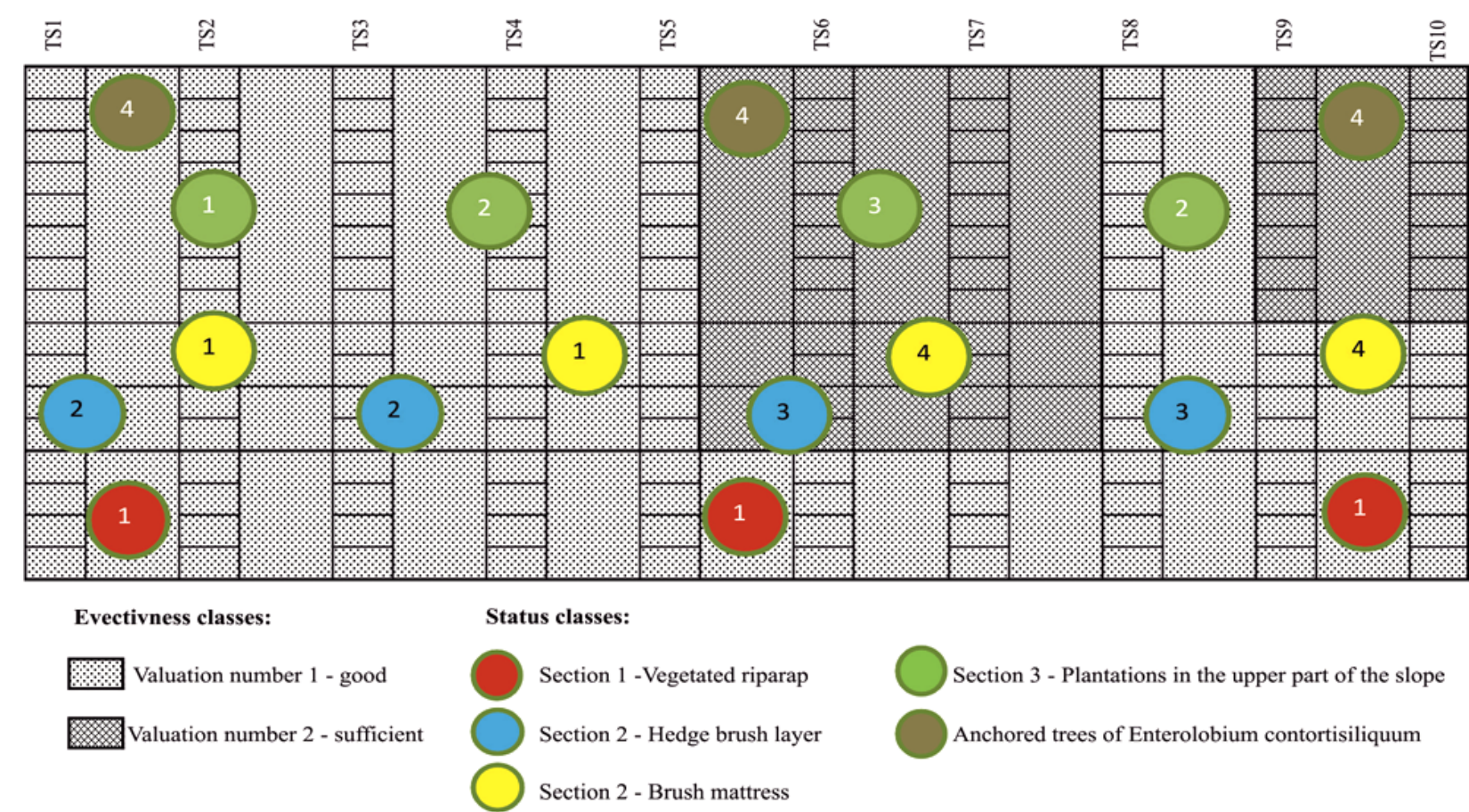

Figure 7.

Evaluation of structures.

Although slope reinforcement was obtained, the high proportion of spontaneous vegetation plus uncovered areas might endanger the stability in the long term. Implemented species which significantly diminished or disappeared completely are not recommendable for further slope reinforcement constructions. The brush mattress showed in half of the construction very good development and seems therefore to be an appropriate construction for the use in soil bioengineering works. However, in view of its large application along the whole construction, the assertiveness against other species seems to be relatively low due to the partial occurrence of Salix humboldtiana, This fact should be considered in further applications of brush mattresses using Salix humboldtiana. In the upper part of the slope, which is only prone to extreme flow conditions in case of flooding, the increase of spontaneous vegetation was partly very high and several fielded species could not develop as expected. This provides important information about the assertiveness of the species used. The sweeping away of the anchored trees of Enterolobium contortisiliquum might be a result of the one-sided anchoring to the slope. A double-sided anchoring might prevent floating in case of flooding.

\section{Discussion of Species}

The strong dominance of Calliandra brevipes shows that it has very good properties to resist against hydraulic shear stress and is applicable to locations with extreme growth conditions like ripraps. Through its very dense growth and production of many shoots, its contribution to soil coverage and consequently to erosion protection is very high. It could also prevail in the upper section of the embankment and is the only species which was present in all portions. Due to its dense growth pattern, no other plants could develop, which is a major reason for its dominance. It proved to be very appropriate for slope reinforce- ment interventions projects, but its dominant characteristics should be considered for further works. As it is both an ornamental brush and a very robust species, it has great potential to be applied at different riverine landscapes.

Phyllanthus sellowianus established best along the mean water level and is compatible with extreme growth conditions, for example temporary submersions. Rauch and Sutili, 2009, already ascertained Phyllanthus sellowianus as a very flexible plant because of a high percentage of gelatinous fibers. By bending, it protects the margin of the river and is very rapture resistant. Moreover, Hörbinger (2013) showed by means of a pull-out test its high pullout resistance and favorable root architecture in terms of root anchorage ability. In the present study, it was confirmed that Phyllanthus sellowianus can deal with hydraulic shear stress and shows very good properties for soil anchorage. It was hardly present above the riprap and it can therefore be assumed that it is a specialist on extreme growth conditions and not very dominating.

Salix humboldtiana proved to be very appropriate to be used in embankment restoration works since it showed a good growth on extreme site conditions. It was, along with Phyllanthus sellowianus, the only species which established at the mean water level. However, the small number of individuals in the riprap shows that Salix humboldtiana could not prevail against the highly dominating Calliandra brevipes. In the upper portion, where Salix humboldtiana could prevail and form shoots, high brushes developed which contributed strongly to the slope reinforcement. The fact that it could not emerge in half of the construction points to a minor assertiveness of the species. Florineth et al. 2006 investigated, among others, Salix humboldtiana, Phyllanthus sellowianus, Calliandra brevipes, Morus nigra, Terminalia australis and Pouteria salicifolia for their ability to sprout from shoots and to produce adventitious roots.

The best properties showed Phyllanthus sellowianus and Sa- 
lix humboldtiana with a satisfying production of adventitious roots and sprouting from shoots. The other mentioned species have not shown the desired results. In the present study, Terminalia australis and Pouteria salicifolia where used in the hedge brush layer and did not show any, or just weak sprouting. Pouteria salicifolia had already completely disappeared at the first performed survey and seems to be ineligible for the use in river restoration works. The number of plant individuals of Terminalia australis increased until the second performed survey, however for the use in a hedge brush layer this species seem to be inapplicable.

Ateleia glazioveana was, in the upper portion of the embankment, the species which had the strongest increase in the plant stand. It can become a tall tree which might be the reason for the strongest increase of the stem diameter of all species. A big stem diameter can be unfavorable in terms of embankment protection because these plants rather break than bend in case of flooding. In the early stage, the plant continues to contribute to the protection of the slope because it is still flexible. However, maintenance work is necessary to prevent an overly strong growth of that species. If maintenance work is neglected, Ateleia glazioveana will become a high grown tree and put shade pressure onto other plant individuals. Moreover, it can cause slope instabilities by its own weight. Morus nigra, not a native species in Brazil, could establish in the section of the hedge brush layer. However, because of the small number of individuals it was not a suppressing species. The spontaneous grass which emerged widely in the hedge brush layer and in the section of the brush mattress constituted of not native species.

Pennisetum purpureum was noticeably the most assertive species of the spontaneous vegetation. The question arises if Pennisetum purpureum with less flood resistance will provide long term slope reinforcement. It seems that some of the implemented vegetation was pushed back by the highly dominating $P$. purpureum. Once the established vegetation has reached a certain height, no further pushing back by $P$. purpureum has to be expected. It is, however possible that $P$. purpureum will be pushed back again in further succession of the plant stand. This, as well as the long term slope reinforcement effect, should be a task for further surveys on site.

\section{Conclusion}

Figure 8 shows an overview of the situation before the intervention (2010) and after 3 years of plant development (2013). The "new" riparian forest based on the application of soil bioengineering techniques fulfills technical as well as ecological functions. The generated forest provides bank protection against erosion and creates new ecological habitats. Furthermore, the project shows that soil bioengineering techniques are

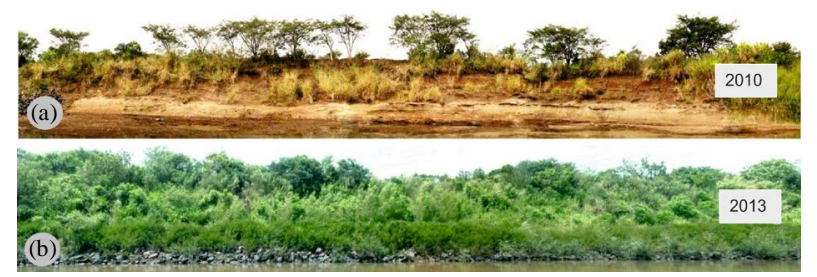

Figure 8.

(a) Embankment before implementation of reinforcement works (Sutili, 2010); and (b) two years after its completion (Hörbinger, 2013). suitable for engineering purposes supposing that both the technique and the local plants are taking into account in the planning and implementation procedure.

\section{REFERENCES}

Acharya, M. S., \& Rauch, H. P. (2008). Pullout test of willows to estimate the mechanical effects of roots [Konferenz]. 2nd International Conference on Ground Bio- and Eco-Engineering-The Use of Vegetation to Improve Slope Stability, Beijing, 14-18 July 2008.

Altreiter, W., \& Plunger, K. (2004). Ingenieurbiologische Maßnahmen am Rio Guardamor in Südbrasilien. Wien: Diplomarbeitan der Universitätfür Bodenkultur,.

Raymond, P. (2012). AMEC environment \& infrastructure design guidelines for erosion and flood control project for streambank and riparian stability restoration [Bericht]. Calgary: City of Calgary.

Bressan, D. A., Durlo, M. A., \& Sutili, F. J. (2004). Potencialbiotécnico do sarandibranco (Phyllanthussellowianus Müll. Arg.) e vime (Salix viminalis L.) para revegetação de margens de cursos de água. Ciência Florestal, Santa Maria, 14, 13-20.

Comitê Pardo (2012). A bacia hidrográfica do rio pardo. http://www.comitepardo.com.br/bacia_riopardo.htm

Denardi, L. (2007). Anatomia e Flexibilidade do Caule de Quatro Espécies Lenhosas Para o Manejo Biotécnico de Cursos de Água. 2007. 111 f. Tese (DoutoradoemManejoFlorestal)_Universidade Federal de Santa Maria, Santa Maria.

Durlo, M. A., Florineth, F., \& Sutili, F. (2006). Endbericht KEF Projekt 121-Ingenieurbiologische Uferschutzmaßnahmen an Bächen und Flüssen in Südbrasilien. Wien: Kommission für Entwicklungsfragen Österreichische Akademie der Wissenschaften.

Durlo, M. A., \& Sutili, F. J. (2005). Bioengenharia: Manejobiotécnico de cursos de água. Porto Alegre: EST Edições, 198.

Florineth F. (2002). Stabilisation of land slides using soil bioengineering methods. Erosion control (pp. 32-38). Santa Barbara: IECA, Official Journal of the International Erosion Control Association.

Gerstgasser, C. (2000). Ingenieurbiologische Bauweisen an Fliessgewässern. Grundlagen zum Bau, Belastbarkeit und Wirkungsweisen. Österreichischer Kunst und Kulturverlag, Wien.

Heuser, S. E. (2013). FEE—Fundação de Economia e Estatística. http://www.fee.tche.br/sitefee/eng/content/resumo/pg_municipios_de talhe.php?municipio=Santa+Cruz+do+Sul

Holanda, F. S. R., \& Pinheiro da Rocha, I. (2010). Streambank Soil Bioengineering Approach to Erosion Control. InTechopen. Universidade Federal de Sergipe, Brazil.

Hörbinger (2013). A pull out test of Phyllanthussellowianus and Sebastianiaschottiana and development of soil bioengineering constructions in Southern Brazil. Master Thesis, Vienna: University of Natural Resources and Life Sciences.

Howell, J. (1999). Roadside bio-engineering. Kathmandu: His Majesty’s Government of Nepal.

Lammeranner, W., Laaha, G., \& Rauch, H. P. (2005). Implementation and monitoring of soil bioengineering measures at a landslide in the Middle Mountains of Nepal. Plant and Soil, 278, 159-170.

Li, M.-H., \& Eddleman, K. E. (2002). Biotechnical engineering as an alternative to traditional engineering methods. A biotechnical streambank stabilization design approach. Landscape and Urban Planning, 60, 225-242.

Monteiro, J. S. (2009). Influência do ângulo de plantionapropagaçãovegetativa de espéciesutilizadasemengenharia natural. 2009. 111f. Dissertação (mestradoem Manejo Florestal). Santa Maria: Universidade Federal de Santa Maria.

Moreno, J. A. (1961). Clima do Rio Grande do Sul. Secretaria da agricultura, Porto Alegre, 42.

Petrone, A., \& Preti, F. (2010). Soil bioengineering for risk mitigation and environmental restoration in a humid tropical area. Hydrological Earth System Sciences, 14, 239-250.

Petrone, A., \& Preti, F. (2008). Suitability of soil bioengineering techniques in Central America: A case study in Nicaragua. Hydrological 
Earth System Sciences, 12, 1241-1248.

Rauch, H. P., \& Sutili, F. (2009). Project 159: Plants for civil engineering structures, final report. Vienna: Comission for Development Studies attheOeAD-GmbH.

Schiechtl, H. M. (1980). Bioengineering for land reclamation and conservation [Buch]. Edmonton: University of Alberta.

Simon, A., \& Collison, J. C. A. (2002). Quantifiying the mechanical and hydrological effects of riparian vegetation on stream banks stability. Earth Surf Process Landforms, 27, 527-546.
Sutili, F. J. et al. (2012) Flexuralbehaviour of selectedriparian plants understaticload. Vienna: Ecological Engineering.

Vargas, C. O. (2007). Característicasbiotécnicas de Phyllanthussellowianus Müll. Arg., Salix x rubensScharank e Sebastianiaschottiana (Müll. Arg.) Müll. Arg. 2007. 84f. Dissertação (Mestradoem Manejo Florestal). Santa Maria: Universidade Federal de Santa Maria.

Zeh, H. (2007). Soil bioengineering. Construction type manual [Buch]. Zürich: vdfHochschulverlag AG, ETH Zürich, 448. 